\title{
Peningkatan Hasil Belajar Kognitif PPKn Siswa SMP Melalui Model Pembelajaran Kooperatif Tipe STAD
}

\section{Nyoman Eka Putrawan ${ }^{*}$ *}

${ }^{1}$ SMPN 3 Sukasada, Bali, Indonesia

\section{A R T I C L E I N F 0}

\section{Article history:}

Received 10 Februari 2019

Accepted 10 Mei 2019

Available online 30 Juni 2019

Kata Kunci:

Model Pembelajaran

Kooperatif; STAD; Hasil

Belajar; PPKn

Keywords:

Cooperative Learning

Model; STAD; Learning

Achievement; Civic

Education

\begin{abstract}
A B S T R A K
Proses pembelajaran di kelas yang membuat hasil belajar siswa rendah merupakan dasar pembuatan penelitian tindakan kelas ini. Penelitian ini dilakukan di kelas VII A di SMP Negeri 3 Sukasada pada semester Genap tahun pelajaran 2017/2018. Data hasil penelitian dikumpulkan menggunakan tes dan dianalisis menggunakan analisis deskriptif. Setelah semua proses dilaksanakan yang dimulai dengan perencanaan, dilanjutkan dengan pelaksanaan diteruskan dengan observasi/pengumpulan data dan diakhiri dengan refleksi yaitu melakukan analisis, hasil analisis data menunjukkan adanya peningkatan. Nilai awal yang rata-rata awalnya masih rendah yaitu 67 dengan ketuntasan belajar baru mencapai 50\% dan pada siklus I sudah meningkat menjadi 71 dengan ketuntasan belajar $60 \%$ dan meningkat signifikan pada Siklus II menjadi 78 dengan ketuntasan belajar 77\%. Data tersebut menunjukkan keberhasilan penelitian tindakan kelas ini sehingga peneliti berkesimpulan bahwa model pembelajaran kooperatif tipe STAD mampu meningkatkan hasil belajar kognitif siswa kelas VII A di SMP Negeri 3 Sukasada.
\end{abstract}

A B S T R A C T

The learning process in the classroom that makes student learning outcomes low is the basis for making this class action research. The research was conducted in class VII A at SMP Negeri 3 Sukasada in the school year 2017/2018. Data from the study were collected using tests and analyzed using descriptive analysis. After all the processes carried out which began with planning, continued with the implementation continued with observation/data collection and ended with a reflection that is doing analysis, the results of data analysis showed an increase. The initial value which was initially low was 67 with learning completeness reaching only 50\%, and in the first cycle, it had increased to 71 with 60\% learning completeness and a significant increase in Cycle II to 78 with 77\% learning completeness. The data shows the success of this class action research so that the researchers concluded that the STAD type cooperative learning model was able to improve the cognitive learning outcomes of class VII A students at SMP Negeri 3 Sukasada.

\footnotetext{
* Corresponding author.

E-mail addresses: eka.putrawan@gmail.com
} 


\section{Pendahuluan}

Pendidikan memiliki peranan yang sangat strategis dalam pembangunan bangsa Indonesia diantaranya guna menciptakan manusia yang berilmu, bertaqwa dan berbudaya untuk menghadapi tantangan di masa depan yang begitu besar dan kompleks. Pendidikan mengupayakan pembentukan peserta didik yang cerdas, terampil serta memiliki wawasan kebangsaan yang terimplementasi dalam kehidupan bermasyarakat an bernegara. Berdasarkan UU No.20 tahun 2003 tentang sistem pendidikan nasional, yakni: Pendidikan adalah usaha sadar dan terencana untuk mewujudkan suasana belajar dan proses pembelajaran agar peserta didik secara aktif mengembangkan potensi dirinya untuk memiliki kekuatan spiritual keagamaan, pengendalian diri, kepribadian, kecerdasan, akhlak mulia, serta keterampilan yang diperlukan dirinya, masyarakat bangsa dan negara (Depdiknas, 2003: 5-6).

Pendidikan mempunyai posisi penting dalam rangka peningkatan kualitas sumber daya manusia. Posisi yang penting tersebut dapat tercapai apabila pendidikan yang dilaksanakan mempunyai kualitas yang memadai. Kualitas pendidikan dapat diketahui dari dua hal, yaitu: kualitas proses dan produk. Suatu pendidikan dikatakan berkualitas proses apabila proses belajar mengajar (PBM) dapat berlangsung secara efektif dan peserta didik mengalami proses pembelajaran yang bermakna. Pendidikan disebut berkualitas produk apabila peserta didik menunjukkan tingkat penguasaan yang tinggi terhadap tugas-tugas belajar sesuai dengan sasaran dan tujuan pendidikan.

Pendidikan dikatakan berkualitas apabila terjadi penyelenggaraan pembelajaran yang aktif, efektif, inovatif, kreatif dan menyenangkan dengan melibatkan semua komponenkomponen pendidikan, seperti mencakup tujuan pengajaran, guru dan peserta didik, bahan pelajaran, strategi atau metode belajar mengajar, alat dan sumber pelajaran serta evaluasi. Komponen-komponen tersebut dilibatkan secara langsung tanpa menonjolkan salah satu komponen saja, akan tetapi komponen tersebut diberdayakan secara bersama-sama.

Pembelajaran kooperatif merupakan sebuah kelompok strategi pengajaran yang melibatkan peserta didik bekerja secara berkolaborasi untuk mencapai tujuan bersama (Eggen and Kauchak, 1996 dalam Trianto, 2009:59). Sedangkan menurut Nasution (1982:46), menyatakan pembelajaran kooperatif adalah suatu pembelajaran yang dibentuk dalam kelompok kecil dengan anggota kelompok bekerjasama mengoptimalkan dirinya dalam belajar untuk menyelesaikan tugas. Mengacu kedua pendapat di atas maka bisa disimpulkan bahwa pembelajaran kooperatif merupakan pembelajaran yang mampu melibatkan peserta didik secara kolaboratif dalam kelompok kecil, yang memberikan ruang dan kesempatan kepada peserta didik untuk berkomunikasi, berinteraksi dan belajar bersama-sama dengan latar belakang yang berbeda. Dengan belajar kooperatif, diharapkan peserta didik memiliki sikap solidaritas dan sportifitas yang tinggi untuk mencapai tujuan bersama.

Menurut Slavin (1995: 143) STAD (Student Teams Achievement Divisions) merupakan salah satu model pembelajaran kooperatif yang paling sederhana, dan merupakan pendekatan yang paling cocok untuk guru yang baru mulai menerapkan model pembelajaran kooperatif dalam kelas. Model ini menjadi relevan bagi guru yang baru mulai menerapkan model pembelajaran kooperatif karena langkah-langkah pembelajaran yang ditempuh sangat sederhana dan mudah dilaksanakan yang mampu mengundang keterlibatan paserta didik dalam pembelajaran sehingga pembelajaran menjadi lebih menarik dan bermakna bagi peserta didik.

Adapun ciri-ciri model pembelajaran kooperatif tipe STAD adalah sebagai berikut. Pertama, peserta didik belajar dan bekerjasama dalam kelompok-kelompok kecil. Peserta didik dibagi kedalam beberapa kelompok-kelompok kecil yang beranggotakan 5 sampai 6 orang. Tiap kelompok terdiri dari angota-anggota yang memiliki tingkat kemampuan, jenis kelamin, dan berasal dari desa berbeda. Dengan adanya heterogenitas anggota kelompok, diharapkan dapat menarik simpati sekaligus memotivasi peserta didik untuk saling membantu untuk menguasai materi sehingga akan tumbuh suatu kesadaran pada diri peserta didik bahwa belajar secara kooperatif cukup menyenangkan. Fungsi utama dari kelompok adalah memastikan bahwa semua anggota kelompok benar-benar belajar. Kelompok-kelompok belajar bertangungjawab atas keberhasilan tiap-tiap anggota kelompok dalam menguasai materi yang diberikan oleh 
guru. Tiap-tiap anggota kelompok harus melakukan yang terbaik untuk kelompok dan kelompokpun harus melakukan yang terbaik untuk membantu tiap anggotanya.

Kedua, memperhatikan skor awal. Skor awal adalah skor yang diperoleh peserta didik dalam pembelajaran sebelumnya. Skor ini dapat diperoleh melalui hasil uji kompetensi awal saat mulai memasuki sekolah SMP Negeri 3 Sukasada. Skor awal akan dibandingkan dengan skor kuis yang diperoleh setelah mengikuti model pembelajaran kooperatif tipe STAD, kemudian selisih skor antara skor awal dengan skor akhir (gain skor) merupakan sumbangan skor anggota kelompok terhadap kelompoknya. Skor awal ini sangat berguna untuk mengetahui perkembangan peserta didik secara individual. Tujuan dari pada skor awal adalah untuk mengetahui apakah skor peserta didik pada tes berikutnya mengalami peningkatan atau penurunan, sehingga guru dapat melakukan refleksi dan membuat formulasi untuk meningkatkan kemampuan peserta didik baik secara individual maupun kelompok.

Ketiga, setelah sekitar satu atau dua periode setelah guru memberikan presentasi dan sekitar satu atau dua periode praktik kerja kelompok, para peserta didik akan mengerjakan kuis individual. Dalam mengerjakan kuis para peserta didik tidak diperbolehkan untuk saling membantu satu sama lain, walapun dalam satu kelompok. Karena tiap peserta didik sudah diberikan tangung jawab secara individual untuk memahami materinya. Inilah keunggulan model pembelajaran kooperatif tipe STAD, di mana kelompok merupakan wahana untuk mencapai keberhasilan bersama, baik secara individual mapun secara berkelompok. Kuis dimaksudkan untuk mengetahui tingkat penguasaan pengetahuan peserta didik secara individual.

Keempat, skor kemajuan individu. Gagasan di balik skor kemajuan individual adalah untuk memberikan kepada tiap peserta didik tujuan kinerja yang akan dapat dicapai apabila mereka bekerja lebih giat dan memberikan kinerja yang lebih baik dari pada sebelumnya. Tiap peserta didik dapat memberikan kontribusi poin yang maksimal kepada kelompoknya dalam sistem skor ini, tetapi tak ada peserta didik yang dapat melakukannya tanpa memberikan usaha mereka yang terbaik. Tiap peserta didik diberikan skor awal, yang diperoleh dari rata-rata kinerja peserta didik tersebut sebelumnya dalam mengerjakan kuis yang sama. Peserta didik selanjutnya akan mengumpulkan poin untuk kelompok mereka berdasarkan tingkat kenaikan skor kuis mereka dibandingkan dengan skor awal mereka (gain skor). Skor kemajuan individu digunakan untuk mengetahui kemajuan peserta didik secara individu. Dalam model pembelajaran koopertif tipe STAD skor kemajuan ini sangat diperlukan untuk menemukan skor kelompok dan menentukan seberapa jauh materi yang diberikan telah terserap.

Kelima, penghargaan kelompok. Langkah pertama sebelum memberikan penghargaan kelompok adalah menghitung rerata kelompok, yang dilakukan dengan cara menjumlahkan skor kemajuan masing-masing anggota kelompok, kemudian jumlah tersebut dibagi dengan jumlah anggota kelompok yang mengikuti kuis. Rerata skor kelompok ini disebut juga skor hasil belajar masing-masing kelompok. Berdasarkan skor hasil belajar tersebut guru memberikan hadiah atau penghargaan berupa predikat kepada masing-masing kelompok yang memenuhi kriteria tertentu.

Adapun sintaks model pembelajaran kooperatif tipe STAD, yaitu (1) membentuk kelompok yang anggotanya lima sampai enam orang secara heterogen, (2) penyajian materi, (3) memberi tugas kepada kelompok untuk dikerjakan oleh anggota-anggota kelompok. Kelompok berkewajiban menjelaskan pada anggota lainnya sampai semua anggota dalam kelompok itu mengerti, (4) memberi kuis/pertanyaan kepada seluruh peserta didik, (5) pemberian penghargaan terhadap kelompok, dan (6) kesimpulan.

Mulyasa (2003: 5) menjelaskan bahwa upaya meningkatkan kualitas pendidikan terus menerus dilakukan dengan baik secara konvensional maupun inovatif. Hal tersebut lebih terfokus lagi setelah diamanatkan bahwa tujuan pendidikan nasional adalah untuk meningkatkan mutu pendidikan pada setiap jenis dan jenjang pendidikan. Peningkatan mutu pendidikan pada awalnya diwujudkan melalui peningkatan mutu pembelajaran di kelas. Berkaitan dengan hal tersebut, guru sebagai tenaga pendidik profesional mempunyai peran sangat penting. 
Guru merupakan salah satu kunci sukses yang menentukan keberhasilan pendidikan, karena apapun tujuan dan putusan-putusan penting tentang pendidikan yang dibuat oleh para pembuat kebijakan sebenarnya dilaksanakan dalam situsasi pembelajaran di kelas. Dalam usaha meningkatkan kualitas pendidikan, salah satunya diperlukan suatu strategi dan metode pembelajaran yang tepat dan jitu. Selama ini guru masih mengalami berbagai kendala dalam menciptakan suasana belajar yang kondusif bagi peserta didik, sehingga guru mengalami kesulitan dalam menarik perhatian peserta didik dan mendorong partisipasi serta keaktifan peserta didik dalam proses belajar mengajar, yang berdampak pada kurang optimalnya prestasi belajar peserta didik. Salah satunya disebabkan penerapan metode pembelajaran yang kurang tepat.

Metode mengajar guru yang kurang tepat akan mempengaruhi peserta didik dalam belajar, yang bermuara pada hasil belajar yang kurang optimal. Untuk itulah guru harus mampu memiliki kepekaan serta kemampuan mengemas pembelajaran sehingga pembelajaran tidak terkesan kaku yang sekaligus mampu mengakomodir serta mengelola partisipasi dan peran peserta didik dalam proses pembelajaran. Untuk mengimbangi realita tersebut, maka guru sebagai agen perubahan harus memiliki ide, konsep dan inovasi dalam pembelajaran, terutama dari strategi pembelajaran yang diterapkan. Paradigma pembelajaran yang lama yang hanya mengembangkan kemampuan kognitif peserta didik saja, harus diubah menjadi paradigma pengajaran baru yang mampu mengembangkan kemampuan kognitif (pengetahuan), afektif (sikap) dan psikomotorik (keterampilan) pada diri peserta didik.

Dalam kenyataannya masih banyak dijumpai permasalahan dalam proses pembelajaran, diantaranya kurangnya perhatian peserta didik dalam pembelajaran yang terlihat dari maraknya peserta didik yang ribut dalam pembelajaran, minimnya sumber belajar peserta didik yang berakibat sulitnya mendapat informasi yang dibutuhkan, komunikasi bersifat satu arah karena dominasi guru dalam pembelajaran terlalu tinggi, penggunaan metode yang monoton sehingga peserta didik kurang diberi ruang untuk berpartisipasi secara optimal dalam pembelajaran. Semua realita diatas akhirnya bermuara dan berdampak pada rendahnya hasil belajar peserta didik.

Berdasarkan hasil observasi, kondisi pembelajaran PPKN peserta didik kelas VII A SMP Negeri 3 Sukasada dapat diidentifikasi masalah-masalah sebagai berikut: 1) rendahnya hasil belajar peserta didik, 2) kurang tertariknya peserta didik untuk belajar PPKN, 3) minimnya partisipasi peserta didik dalam menjawab pertanyaan guru, 4) peserta didik kurang mampu menyampaikan pendapat 5) pembelajaran masih berpusat pada guru. Permasalahan yang dihadapi tersebut akan bermuara pada rendahnya hasil belajar peserta didik kelas VII A. Ini dilihat dari nilai rata-rata ulangan harian peserta didik yang hampir $50 \%$ di bawah KKM mata pelajaran PPKN.

Guna mengatasi permasalahan yang terjadi dan dialami dalam pembelajaran PPKN maka salah satu alternatif yang digunakan adalah dengan menerapkan model pembelajaran kooperatif tipe STAD (Student Teams Achievement Divisions). Dalam kelas kooperatif, para peserta didik diharapkan dapat saling mendiskusikan, saling berargumentasi serta saling membantu untuk mengasah dan meningkatkan kemampuan peserta didik sehingga mampu meminimalis kekurangan sekaligus menularkan kelebihan pemahaman terhadap materi PPKN yang nantinya mampu mengurangi kesenjangan diantara peserta didik.

Melalui pembelajaran kooperatif, guru diharapkan dapat mengelola kelas dengan lebih efektif. Selain guru, peserta didik juga diharapkan lebih bertanggung jawab terhadap tugasnya serta dapat menumbuhkan rasa saling ketergantungan antar teman sejawat di dalam kelompoknya. Dalam teknik pembelajaran kooperatif tipe STAD kegiatan belajar mengajar berpusat pada peserta didik. Antar anggota kelompok dapat saling membantu untuk memecahkan permasalahan secara bersama-sama dengan perantara diskusi. Berangkat dari permasalahan di atas maka peneliti tertarik untuk memecahkan masalah pembelajaran PPKN peserta didik kelas VII A dengan melakukan penelitian Penerapan Model Pembelajaran Kooperatif Tipe STAD (Student Teams Achievement Divisions) Untuk Meningkatkan Hasil Belajar PPKN Peserta didik Kelas VII A SMP Negeri 3 Sukasada Semester Genap Tahun Pelajaran 2017 - 2018. 


\section{Metode}

Penelitian tindakan kelas ini dilaksanakan di SMP Negeri 3 Sukasada, khususnya di kelas VII A semester genap tahun pelajaran 2017/2018. Subjek penelitian ini adalah seluruh peserta didik kelas VII A SMP Negeri 3 Sukasada Semester Genap , Tahun Pelajaran 2017/2018 yang berjumlah 30 orang dengan rincian laki-laki sebanyak 14 orang dan perempuan sebanyak 16 orang. Objek penelitian meliputi model pembelajaran kooperatif tipe STAD dan hasil belajar. Adapun definisi dari objek penelitian ini adalah: (1) model pembelajaran kooperatif tipe STAD adalah model pembelajaran yang dirancang dengan menggunakan langkah-langkah pembelajaran yang meliputi penyampaian tujuan oleh guru, menyajikan informasi, mengorganisir peserta didik ke dalam kelompok belajar, membimbing peserta didik dalam kelompok, evaluasi dan pemberian penghargaan kepada peserta didik yang hasil belajarnya terbaik, dan (2) hasil belajar adalah hasil yang dicapai oleh peserta didik setelah mengalami proses belajar baik yang menyangkut ranah kognitif, afektif, ataupun psikomotor yang ditunjukkan melalui tes atau angka.

Penelitian ini adalah penelitian tindakan kelas (PTK) atau yang biasa disebut Classroom Action Research (CAR) yang bertujuan untuk mengadakan perbaikan dan meningkatkan proses pembelajaran. PTK merupakan suatu tindakan atau aktivitas yang berbentuk siklus dan sengaja dilakukan dengan tujuan untuk memecahkan masalah, peningkatan kualitas pembelajaran di kelas, serta untuk meningkatkan kualitas hasil pembelajaran melalui perbaikan pembelajaran di kelas. Menurut Arikunto, (2008: 16) ada empat langkah penelitian tindakan kelas, yaitu : (1) perencanaan, (2) pelaksanaan, (3) pengamatan, dan (4) refleksi.

Teknik pengumpulan data yang digunakan adalah dalam bentuk tes dan obervasi. Tes yang dikembangkan untuk mengukur ranah kognitif peserta didik menggunakan tes objektif yang dikembangkan sendiri oleh peneliti. Tes yang dikembangkan dan digunakan adalah tes objektif pilihan ganda dengan 4 pilihan yang memuat satu jawaban yang paling benar. Observasi adalah teknik pengumpulan data yang dilakukan secara sistematis dan sengaja yang dilakukan melalui pengamatan dan pencatatan gejala-gejala yang diselidiki. Untuk mengukur hasil belajar ranah afektif dalam pembelajaran PPKN dilakukan dengan menggunakan teknik observasi. Observasi yang dikembangkan dalam penelitian ini menggunakan lembar observasi yang berisi sejumlah penilaian terhadap sikap peserta didik selama proses pembelajaran. Untuk menilai keterampilan peserta didik dalam pembelajaran PPKN diukur dengan menggunakan teknik observasi. Observasi yang dikembangkan dalam penelitian ini menggunakan lembar observasi yang berisi sejumlah penilaian terhadap keterampilan peserta didik dalam diskusi dan presentasi.

Prosedur penelitian tindakan ini terdiri atas dua siklus. Setiap siklus dengan alur : perencanaan/planning, pelaksanaan/action, pengamatan dan penilaian/observing and evaluation, dan refleksi/reflection. Indikator kinerja atau keberhasilan merupakan suatu kriteria yang digunakan untuk melihat tingkat keberhasilan kegiatan Penelitian Tindakan Kelas (PTK) yang dilaksanakan dalam upaya meningkatkan atau memperbaiki hasil belajar siswa. 1 .

Keberhasilan peserta didik dalam meningkatkan hasil belajar kognitif apabila nilai ratarata kelas sama dengan atau lebih besar dari kriteria ketuntasan minimal (KKM $=72)$. Sedangkan keberhasilan peserta didik dalam meningkatkan hasil belajar afektif dan psikomotor apabila nilai yang diperoleh peserta didik minimal berkualifikasi Baik.

\section{Hasil dan pembahasan}

\subsection{Pembelajaran Prasiklus}

Penelitian tindakan kelas ini dilakukan di kelas VII A SMP Negeri 3 Sukasada pada Semester Genap Tahun Pelajaran 2017 / 2018 dengan subjek penelitian terdiri dari 30 orang dengan rincian laki-laki sebanyak 14 orang dan perempuan sebanyak 16 orang. PTK dilaksanakan selama 3 bulan dimulai dari bulan Januari sampai bulan Maret 2018

Sebelum melakukan PTK, peneliti melakukan observasi awal atau studi pendahuluan mengenai hasil belajar peserta didik kelas VII A SMP Negeri 3 Sukasada. Teknik yang digunakan selama observasi awal adalah teknik wawancara serta hasil tes. Berdasarkan hasil wawancara diketahui bahwa peserta didik kurang terlatih untuk mengemukakan gagasan atau pendapat ketika guru 
mengajukan pertanyaan serta rendahnya keterlibatan peserta didik dalam proses pembelajaran PPKN. Selain ini, nilai tes hasil belajar peserta didik tergolong rendah, dan sebagian besar di bawah KKM.

\subsection{Peningkatan Hasil Belajar PPKn pada Siklus 1} sebagai berikut.

Siklus pertama dalam penelitian tindakan kelas ini mencangkup beberapa langkah

1) Perencanaan

Setelah observasi awal yang dilakukan peneliti, maka kelas yang dijadikan penelitian adalah kelas VII A dengan jumlah peserta didik 30 orang. Persiapan yang dilakukan peneliti terlebih dahulu dikonsultasikan dengan guru sebagai rekan sejawat atau mitra dalam penelitian. Penelitian tindakan kelas pada siklus 1, mengacu pada Bab 4 "Keberagaman suku, Agama, Ras, dan Antargolongan dalam Bingkai Bhineka Tunggal Ika", dan KD" Mengidentifikasi keberagaman suku, agama, ras, dan antargolongan dalam bingkai Bhineka Tunggal Ika, serta Indikatornya adalah Menganalisis faktor penyebab keberagaman masyarakat Indonesia. Untuk mencapai tujuan pembelajaran tersebut, perencanaan pembelajaran dirancang untuk 2 kali pertemuan, setiap pertemuan dialokasikan waktu $3 \times$ 40 menit, jadi untuk 2 x pertemuan alokasi waktunya $6 \times 40$ menit.

2) Pelaksanaan Tindakan

Pelaksanaan tindakan dilaksanakan sesuai dengan jadwal pembelajaran di kelas. Pelaksanaan pembelajaran dirancang untuk 2 kali pertemuan dengan alokasi waktu (6 x 40 menit) selama 2 minggu, setiap minggu dilaksanakan satu kali yaitu pada hari kamis.

3) Observasi Penilaian

Pada penelitian ini observasi dilakukan terhadap hasil belajar kognitif. Data hasil belajar kognitif pada siklus 1 diperoleh dari tes evaluasi yang diberikan pada akhir siklus. Tes evaluasi yang diberikan berupa tes obyektif sebanyak 15 soal. Dari hasil tes ini akan diketahui rata-rata kelas, ketuntasan belajar dan daya serap peserta didik seperti terlihat pada Gambar 1.

Hasil belajar kognitif siklus 1

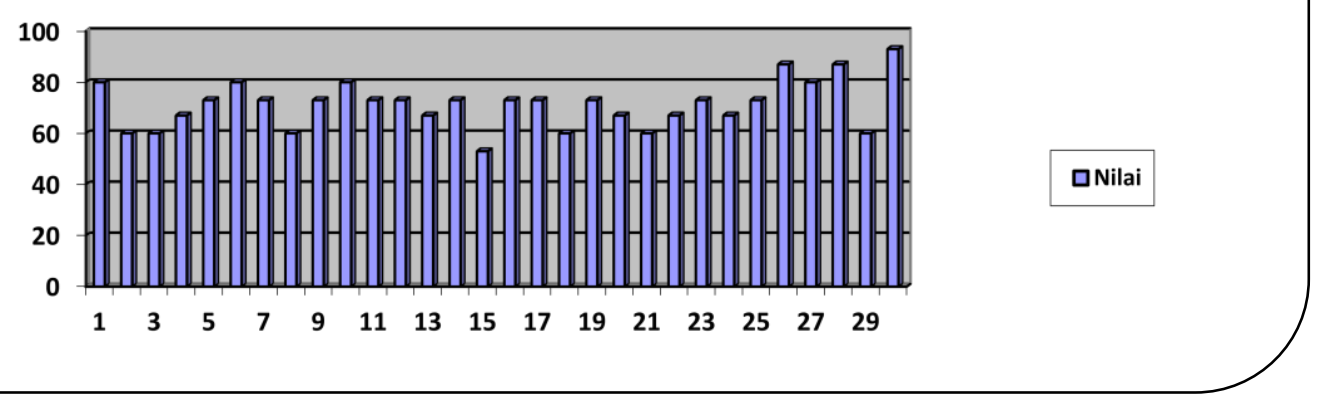

Gambar 1. Grafik Hasil Belajar Kognitif Siklus 1

Berdasarkan Gambar 4, maka nilai terendah yang diperoleh peserta didik adalah 53 dan tertinggi adalah 93. Jumlah nilai dari seluruh peserta didik yang mengikuti tes adalah 2138 dengan rata-rata 71 . Ketuntasan belajar peserta didik $60 \%$ dan daya serap peserta didik adalah $71 \%$. Jumlah peserta didik yang mencapai KKM sebanyak 18 orang (60 \%) dan yang belum tuntas mencapai KKM sebanyak 12 orang (40\%).

4) Refleksi

Berdasarkan hasil observasi dan tes hasil belajar peserta didik, maka dapat disimpulkan tindakan pada siklus 1 sudah dapat terlaksana dengan baik. Akan tetapi perolehan hasil belajar peserta didik belum maksimal karena masih banyak peserta didik yang memperoleh 
nilai dibawah KKM. Hasil belajar kognitif menunjukkan jumlah peserta didik yang belum mencapai KKM adalah 12 orang (40\%), hasil belajar afektif menunjukkan jumlah peserta didik yang masih memperoleh kategori nilai cukup sebanyak 7 orang (23\%) dan hasil belajar psikomotor menunjukkan jumlah peserta didik yang masih memperoleh kategori nilai cukup sebanyak 15 orang (50\%).

Hasil belajar yang diperoleh pada siklus 1 menunjukkan perlu adanya perbaikan dan pembenahan untuk memperoleh hasil yang lebih baik. Oleh karena itu, kendala-kendala yang dialami dalam pembelajaran pada siklus 1 perlu diperbaiki dan dibenahi. Adapun kendala-kendala yang dihadapi adalah: (1) peserta didik belum terbiasa untuk melakukan diskusi, terlihat situasi kelas ribut dan peserta didik kebanyakan mengobrol dengan temannya dan kurang memperhatikan penjelasan guru, (2) peserta didik belum terbiasa mengajukan pertanyaan sehingga masih banyak mendapat arahan dari guru, (3) peserta didik masih malu menyampaikan pendapat sendiri, dan cenderung menunggu pendapat teman yang dianggap lebih mampu dalam kelompok, dan (4) kegiatan diskusi membutuhkan waktu yang banyak, karena peserta didik belum selesai mengerjakan soalsoal sehingga mengurangi alokasi waktu untuk kegiatan presentasi.

\subsection{Peningkatan Hasil Belajar PPKn pada Siklus 2}

Siklus 2 merupakan perbaikan dari proses pembelajaran pada siklus 1 sekaligus penyempurnaan terhadap kendala-kendala yang dihadapi pada siklus 1 . Perbaikan yang dilakukan pada siklus 2 terkait dengan memotivasi belajar peserta didik, pengalokasian waktu yang sesuai dengan rancangan pembelajaran serta hasil belajar. Adapun langkah-langkah yang dilakukan pada siklus 2 sebagai berikut.

1) Perencanaan

Perencanaan tindakan pada siklus 2 sama dengan tindakan pada siklus 1 , hanya saja pada siklus 2 lebih ditekankan pada hal-hal yang dianggap jadi penyebab kurang berhasilnya kegiatan pembelajaran pada siklus 1 . Penelitian tindakan kelas pada siklus 2, mengacu pada materi Keberagaman Suku, Ras, Agama, dan Antargolongan.

2) Pelaksanaan Tindakan

Pelaksanaan tindakan dilaksanakan sesuai dengan jadwal pembelajaran di kelas dengan durasi 2 kali pertemuan. Pembelajaran dilaksanakan dengan alokasi waktu 3 x 40 menit (3 jam pelajaran) setiap satu kali pertemuan dalam setiap minggu yang dilaksanakan pada hari kamis.

3) Obervasi Penilaian

Data hasil belajar kognitif pada siklus 2 diperoleh dari tes evaluasi yang diberikan pada akhir siklus. Tes evaluasi yang diberikan berupa tes obyektif sebanyak 20 soal. Dari hasil tes ini akan diketahui rata-rata kelas, ketuntasan belajar dan daya serap peserta didik. Adapun analisis data hasil belajar kognitif pada siklus 2 dapat disajikan pada Gambar 2.

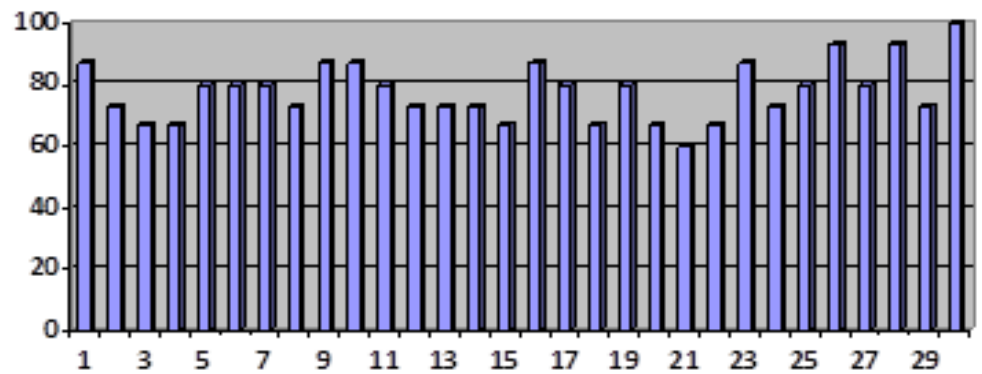

Gambar 2. Grafik Hasil Belajar Kognitif siklus 2 
Berdasarkan Gambar 2, maka nilai terendah yang diperoleh peserta didik adalah 67 dan tertinggi adalah 100. Jumlah nilai dari seluruh peserta didik yang mengikuti tes adalah 2334 dengan rata-rata 78 . Ketuntasan belajar peserta didik $77 \%$ dan daya serap peserta didik adalah $78 \%$.

4) Refleksi

Berbagai kendala yang dialami pada siklus 1, telah dilakukan perbaikan dan penyempurnaan untuk meningkatkan hasil belajar pada siklus 2. Adapun perbaikanperbaikan yang dilakukan seperti pengalokasiaan waktu yang sesuai rancangan pembelajaran sehingga kegiatan awal, inti sampai penutup dapat terlaksana dengan baik. Peserta didik mulai terbiasa melakukan diskusi kelompok sehingga komunikasi dalam mengeluarkan pendapat lebih maksimal dibandingkan dengan siklus 1 . Proses pembelajaran terpusat pada peserta didik dan guru hanya sebagai fasilitator. Peserta didik berani menjawab pertanyaan dan mengmukakan pendapat setelah motivasi-motivasi yang diberikan oleh guru.

Berdasarkan hasil evaluasi yang telah dilakukan maka penelitian tindakan kelas dengan menerapkan model pembelajaran kooperatif tipe STAD di kelas VII A SMP Negeri 3 Sukasada, dikatakan berhasil karena tujuan pembelajaran telah tercapai dan seluruh peserta didik telah mencapai ketuntasan dalam pembelajaran.

\subsection{Pembahasan}

Penelitian tindakan kelas yang dilakukan di kelas VII A SMP Negeri 3 Sukasada Semester Genap Tahun Pelajaran 2017/2018 dilaksakan dalam 2 siklus. Untuk memberikan gambaran keberhasilan tindakan dan terjadi peningkatan hasil belajar dari skor awal peserta didik sebelum dilakukan tindakan dengan siklus 1 dan siklus 2. Berdasarkan hasil analisis, ditemukan bahwa terjadi peningkatan hasil belajar dari sebelum dilakukan tindakan dan setelah dilakukan tindakan. Peningkatan hasil dapat dilihat dari jumlah rata-rata nilai peserta didik pada tes awal adalah 67, kemudian setelah dilaksanakan siklus 1 terjadi peningkatan rata-rata dengan jumlah 71. Peningkatan rata-rata dari nilai tes awal sampai siklus 1 belum menunjukkan peningkatan signifikan, karena baru 50\% peserta didik yang mencapai KKM $=72$. Selanjutnya pelaksanaan siklus 2 menunjukkan hasil yang memuaskan dimana rata-rata hasil belajar peserta didik adalah 78 dengan ketuntasan belajar $77 \%$.

Dengan membandingkan nilai hasil belajar awal, pelaksanaan siklus 1 dan siklus 2, maka pembelajaran PPKN dengan menerapkan model pembelajaran kooperatif tipe STAD, mampu meningkatkan hasil belajar. Pembelajaran kooperatif tipe STAD merupakan salah satu model pembelajaran kooperatif yang paling sederhana, dan merupakan pendekatan yang paling cocok dikembangkan dalam kelas heterogen (Purwanti dan Gafur, 2018). Dengan adanya heterogenitas anggota kelompok, diharapkan dapat memotivasi peserta didik untuk saling membantu untuk menguasai materi sehingga akan tumbuh suatu kesadaran pada diri peserta didik bahwa belajar secara kooperatif cukup menyenangkan. Fungsi utama dari kelompok adalah memastikan bahwa semua anggota kelompok benar-benar belajar, dan lebih khususnya lagi adalah mempersiapkan anggotanya untuk mengerjakan kuis/tes dengan baik (Nurhayati, 2014; Yanti, Sunu dan Sudiatmaka, 2014). Kelompok-kelompok belajar bertangungjawab atas keberhasilan tiap-tiap anggota kelompok dalam menguasai materi yang diberikan oleh guru. Tiap-tiap anggota kelompok harus melakukan yang terbaik untuk kelompok dan kelompokpun harus melakukan yang terbaik untuk membantu tiap anggotanya. Sejalan dengan hasil penelitian ini, Yulianti (2018) menemukan bahwa peserta didik akan semakin antusias untuk meningkatkan hasil belajar karena setiap akhir pembelajaran guru memberikan penghargaan kepada kelompok yang mampu mencapai nilai yang paling baik. Pada penelitian lain, peserta didik mulai terbiasa untuk mengemukakan pendapat tanpa adanya rasa malu karena semua peserta didik akan berlomba-lomba untuk memperoleh hasil terbaik demi kemajuan kelompok (Cahyani, Tegeh dan Sudarma, 2015). Oleh karena itu, model pembelajaran kooperatif tipe STAD mampu memupuk sikap kerjasama, disiplin, tanggung jawab dan jujur pada diri peserta didik. 
Berdasarkan perbandingan data hasil belajar siklus 1 dan siklus 2, maka terjadi peningkatan hasil belajar dan ini menunjukan tindakan penelitian kelas dikatakan berhasil karena seluruh peserta didik pada siklus 2 telah mencapai KKM.

\section{Simpulan dan saran}

Berdasarkan hasil analisis data dalam penelitian tindakan kelas, maka dapat disimpulkan bahwa penerapan model pembelajaran kooperatif tipe STAD dapat meningkatkan hasil belajar PPKN peserta didik kelas VII A SMP Negeri 3 Sukasada Semester Genap Tahun Pelajaran 2017/2018. Peningkatan hasil belajar dapat dilihat dari adanya peningkatan rata-rata hasil belajar awal dibandingkan dengan siklus 1 dan siklus 2. Hasil belajar kognitif pada siklus 1 menunjukkan peserta didik yang mencapai ketuntasan belajar sebesar $60 \%$, dengan rata-rata nilai 71 dan daya serap 71\%. Pada siklus 2 hasil belajar kognitif menunjukkan peserta didik yang mencapai ketuntasan belajar sebesar 77\%, dengan rata-rata nilai 78 dan daya serap $78 \%$.

Mengacu kepada hasil penelitian tindakan ini, maka dapat disampaikan saran-saran sebagai berikut. Bagi Guru, penerapan model pembelajaran kooperatif tipe STAD dapat digunakan bagi guru yang baru mulai menerapkan model pembelajaran kooperatif karena langkah-langkah pembelajaran yang ditempuh sangat sederhana dan mampu membuat pembelajaran menjadi lebih menarik dan bermakna bagi peserta didik. Selain itu, dengan menerapkan model pembelajaran kooperatif tipe STAD dapat meningkatkan hasil belajar. Bagi peneliti sejenis, selanjutnya diharapkan membuat kajian yang lebih mendalam terkait dengan penerapan model pembelajaran kooperatif tipe STAD tidak hanya untuk meningkatkan hasil belajar semata, tetapi dapat juga untuk meningkatkan motivasi dan minat peserta didik dalam belajar PPKN.

\section{Daftar Rujukan}

Andriyani, L. 2011. Pengembangan Perangkat Pembelajaran Fisika Berbasis Inkuiri Untuk Siswa Kelas XII IPA Sekolah Menengah Atas. Tesis (tidak diterbitkan). Bandar Lampung : Universitas Lampung.

Arikunto, S. 2008. Penelitian Tindakan Kelas. Jakarta: Bumi Aksara.

Aryani, N. I. L. 2012. Upaya Peningkatan Hasil Belajar IPS MelaluiPembelajaran Kooperatif Tipe STAD (Student Teams Achievement Divisions) Kelas IV A MIN Yogyakarta II Tahun Ajaran 2011/2012. Skripsi (tidak diterbitkan). Yogyakarta: Program Studi Pendidikan Guru Madrasah Ibtidaiyah Fakultas Tarbiyah dan Keguruan UIN Sunan Kalijaga.

Cahyani, I G. A. A. N., Tegeh, I M., dan Sudarma, I K. 2015. Pengaruh Model Pembelajaran Kooperatif Tipe STAD Berbantuan Multimedia Pembelajaran Terhadap Hasil Belajar PKn. Edutech, Vol. 3 (1).

Depdiknas. 2003. Undang-Undang Nomor 20 Tahun 2003 tentang Sistem Pendidikan Nasional. Jakarta: Depdiknas.

Hamalik, 0. 2001. Proses Belajar Mengajar. Jakarta : Bumi Aksara.

Muhamad, H. 2014. Panduan Penilaian Pendapaian Kompetensi Peserta Didik Sekolah Menengah Pertama. Jakarta: Kemendibud.

Nasution, S. 1982. Berbagai Pendekatan Dalam Proses Belajar \& Mengajar. Jakarta: PT. Bumi Perkasa

National Council for the Social Studies. 1994. Conecting Science, Technology and Education of Citizen. Washington D.C: NCSS

Nur, M. 1998. Pendekatan-Pendekatan Konstruktivisme Dalam Pembelajaran. Surabaya: PPs IKIP.

Nurhayati. 2014. Penerapan Model Pembelajaran Kooperatif Tipe STAD Untuk Meningkatkan Hasil Belajar PKn Peserta Didik Pada MTs. Islamiyah Palangka Raya. Pedagogik Jurnal Pendidikan, Vol. 9 (1): 64-69.

Nurkancana, W. 1992. Evaluasi Hasil Belajar. Surabaya: Usaha Nasional.

Peraturan Menteri Pendidikan Nasional Republik Indonesia Nomor 23 Tahun 2006, Tentang Standar Kompetensi Lulusan (SKL) Untuk Satuan Pendidikan Dasar dan Menengah. 
Purwanti, S. dan Gafur, A. 2018. Penerapan Pembelajaran Kooperatif Tipe STAD Untuk Meningkatkan Motivasi Dan Hasil Belajar PKn. SOCIA: Jurnal Ilmu-Ilmu Sosial, Vol. 15(2): 140-148.

Purwanto, M. N. 2011. Prinsip-Prinsip dan Teknik Evaluasi Pengajaran. Bandung: PT Remaja Rosdakarya.

Saidihardjo. (1996). Konsep Dasar Ilmu Pengetahuan Sosial. Jakarta. FIP IKIP.

Slavin, R. (2005). Cooperative Learning: Theory, Research and Practice. London: Allymand Bacon.

Trianto. 2009. Mendesain Model Pembelajaran Inovatif-Progresif, Konsep, Landasan, dan Implementasinya Pada Kurikulum Tingkat Satuan Pendidikan (KTSP). Jakarta: Kencana.

Wahab, A. A. 1998. Reorientasi dan Revitalisasi Pendidikan Ilmu-ilmu Sosial. Bandung: Program Pascasarjana IKIP Bandung.

Yanti, K. I., Sunu, I G. K. A., dan Sudiatmaka, K. 2014. Penerapan Model Pembelajaran Kooperatif Tipe STAD Untuk Meningkatkan Hasil Belajar PKn Siswa. Jurnal Pendidikan Kewarganegaraan, Vol. 2(1).

Yulianti, M. 2018. Pelaksanaan Model Pembelajaran Kooperatif Tipe STAD Untuk Meningkatkan Hasil Belajar PPKn Siswa SMP Negeri 3 Teluk Kuantan. Jurnal PAJAR, Vol. 2(5): 789-794. 